\title{
REMUNERATION AND PERFORMANCE
}

\author{
Iriani Ismail \\ Universitas Trunojoyo, Madura, Indonesia
}

\begin{abstract}
The aim of this study is to explain the role of remuneration in improving the performance of library employees. This study uses the qualitative method which the population is all employees numbering 17 people. Based on interactive analysis methods and ethnographic techniques, its took In-depth interview and observations. Using this analysis, the result showed that the remuneration has an important role in improving employees performance. Some internal and external factors influence it so that optimal performance is obtained. Generally, employees expect that the remuneration has been high to be accepted like as expected. Most employees demands such remuneration to meet their daily needs. External factors also has a strong role so the employees demand high, but not balanced with high performance.
\end{abstract}

\section{Inroduction}

Performance is something that is often discussed to determine or provide direction for the development of the next employee. This human resource becomes a center that must be considered and addressed its performance. Human resources as employees are an important component in the delivery of services to the community. Employees will be assured of their welfare if all of the employee's needs can be fulfilled, including economic needs which in this case are realized in the system of providing performance benefits (remuneration). Therefore, the needs to be a change in the reward system that is only based on position and education, without considering the performance that has been done by employees for the organization (Siagian, 2014: 262)

Remuneration is a part of reward received employees as a result of their task in the organization, including gifts, awards or promotions. Performance cannot be achieved optimally if remuneration is not given proportionally. In addition, the individual's attachment to work is the key to the success and profitability of the organization. The use of remuneration in return for educators in the university environment as well as being a form of independence is also the responsibility of the leadership in improving job satisfaction and work motivation. Basically, the existence of these benefits has fulfilled the expectations of the teaching staff at work. Rivai, et al (2014) explained that someone can act something (in an effort to achieve goals and fulfill responsibilities) that tends to be due to the expectation of the results to be obtained. The statement explains that the nature of the employee works (doing something) because there is hope to get a reply that can be in the form of remuneration. So that when the needs and expectations of employees are fulfilled, work satisfaction can be achieved which in turn will affect work motivation. The institution 
strives to improve job satisfaction and work motivation, not least because basic needs are to get quality work from its employees. The quality of work, enthusiasm for work and morale can be realized when the employees were satisfied and work motivation can be obtained. The function of remuneration is clearly a stimulant for job satisfaction and work motivation, in general by referring to the theory of job satisfaction and previous research which examined how much influence the reward with job satisfaction and work motivation with the acquisition of positive influential results. The implementation of remuneration in the university environment is considered new, so the research is intended to examine the effect of remuneration on job satisfaction and work motivation in the university environment, especially in library unit.

Companies really need employees who have high employee engagement because if the company has high employee engagement, it will be able to provide higher returns compared to companies whose employees do not have high employee engagement with their work. Employees who have a high sense of employee engagement, will work seriously so that the resulting work can contribute well to the progress of the company.

This study was conducted at the Library unit (department). The performance of employees in this institution is quite good because it has been able to achieve performance as planned by the University. The library unit is got a new ISO and accredited. ISO 2015 is the latest ISO, already owned. Performance appraisal in that section is held once a year, this is intended to determine the increase or decrease in the performance of its employees, which will later become an evaluation for the library to improve employees performance. Employees do their works referring to the SOP (Standard Operating Procedure) that has been set.

From the results of interviews with several employees, the remuneration that the employees felt it was good enough and fair and decent. This can be proven by a system of remuneration based on performance appraisal carried out by library management. Provision of remuneration is given objectively in accordance with the workload and performance that has been generated by these employees. The amount of remuneration at this institution is based on the grade and or position. In the certain contexts related to discipline, the grade is ignored. This makes employees more careful so that can reach the expected and set value. Non-financial remuneration given to employees is in the form of a promotion or a grade. Employees have a high sense of employer engagement, this can be evidenced by direct observation in the field when working, where the employees look earnest and passionate even though they are not supervised by the leadership, but they remain fully concentrated and serious doing their jobs.

\section{Literature Review}

\section{Remuneration}

Sofa (2008) found that remuneration is a reward, or remuneration is given to workers or employees as a result of the achievements that have been given in order to achieve organizational goals.

Organizations in giving responsibility to employees to generate contributions in achieving goals must be balanced with reward. Providing rewards is the obligation of the organization to provide services to employees who have carried out their duties or responsibilities. Giving rewards in practice uses 3 determining indicators, namely giving based on performance (Pay for performance), giving based on position or position (Pay for position) and giving based on individuals (pay for person). Current pay for performance that starts frequently and is generally used to determine the amount of compensation, where the approach is often referred to as the remuneration system. Remuneration System has a remunerate base word which means paying or can also be called payroll (Echols and 
Shadily in Roberia, 2009). In practice, remuneration is given to employees on the basis of an employment relationship, where when a job has been completed, remuneration can be received. In general, there are many opinions that judge that remuneration has similarities with compensation. But what needs to be understood is that in remuneration there is no acknowledgment of non-financial returns so that there is a difference with the concept of compensation for that (Roberia, 2009). Remuneration has become an indispensable instrument from an organization both private and public, especially for public organizations that have used a lot of remuneration systems. In the context of the company, remuneration is interpreted as an act of repayment of services or compensation received by employees / workers from employees for the achievements given by workers in order to realize company goals (Pora, 2011: 3).

Mahmudi (2007: 167) said that the main purpose of giving remuneration is as follow:

a. To attract people who are competent, qualified, and characterized by joining the organization.

b. To maintain people who have excellence, competence, quality and good character who have joined the organization so as not to leave the organization.

c. To keep the people in the organization willing to work because inadequate remuneration allows employees to carry out a strike which actually is very detrimental to the organization.

d. To motivate employees to achieve the best performance.

There are five remuneration indicators according to Santoso (2012) including the following:

1. Merit system, namely the determination of employee income based on position.

2. Fair, in the sense that the position with the workload and responsibility of work with the same weight is paid equally and work that demands higher knowledge, skills and responsibilities is paid more.

3. Eligible, that is, it can fulfill the needs of a decent life (not minimum).

4. Competitive, where the salary of civil servants is equivalent to the salary of employees with the same qualifications in the private sector, in order to avoid brain drain.

5. Transparent, in the sense that employees only get official salaries and benefits.

\section{Performance}

Performance is the result of work that can be achieved by a person or group of people in the organization, in accordance with their respective authorities and responsibilities, in order to achieve the objectives of the organization in question, not illegal and in accordance with morals and ethics (Sedarmayanti, 2011: 239) .

Moeheriono (2012: 95) said that performance is a description of the level of achievement of an activity program or policy in realizing the organization's goals, objectives, vision and mission as outlined through the organization's strategic planning.

Mangkunegara (2009: 68) said that the factors that influence employee performance are as follows:

a. Ability Factor

Psychologically, employee's ability consists of potential ability (IQ) and reality ability (knowledge + skill). Employees need to be placed in jobs that match their expertise.

\section{b. Motivation Factor}

Motivation is formed from the attitude (attitude) of an employee in the face of work situations. Motivation is a condition that moves employees who are directed to achieve organizational goals.

In this study the indicators used in evaluating employee performance include: 
1. Individual Personality Ability, which consists of; integrity, enthusiasm, creativity, organizational commitment, guiding, taking strategic decisions, service orientation, and leadership

2. Job Results Targets consisting of; output of work, level of discipline, communication and performance alignment.

Relationship of Remuneration to Employees Performance

Jumaslini (2011: 110), stated that the performance itself cannot be achieved optimally if the remuneration is not given proportionally. Remuneration is basically a tool to realize the vision and mission of the company/organization with the aim of attracting competent and experienced employees, maintaining qualified employees and motivating employees to work effectively. Its existence in an organization cannot be ignored simply because it will be directly related to the achievement of goals (Fitria et al, 2014: 4).

With the provision of remuneration in accordance with what is expected, it will be able to encourage employees performance improvement, so that they are motivated to always try to be the best, this will benefit employees and the company. Effect of remuneration in improving employee performance by increasing employee welfare, with special attention to employee welfare through remuneration.

Framework of thinking

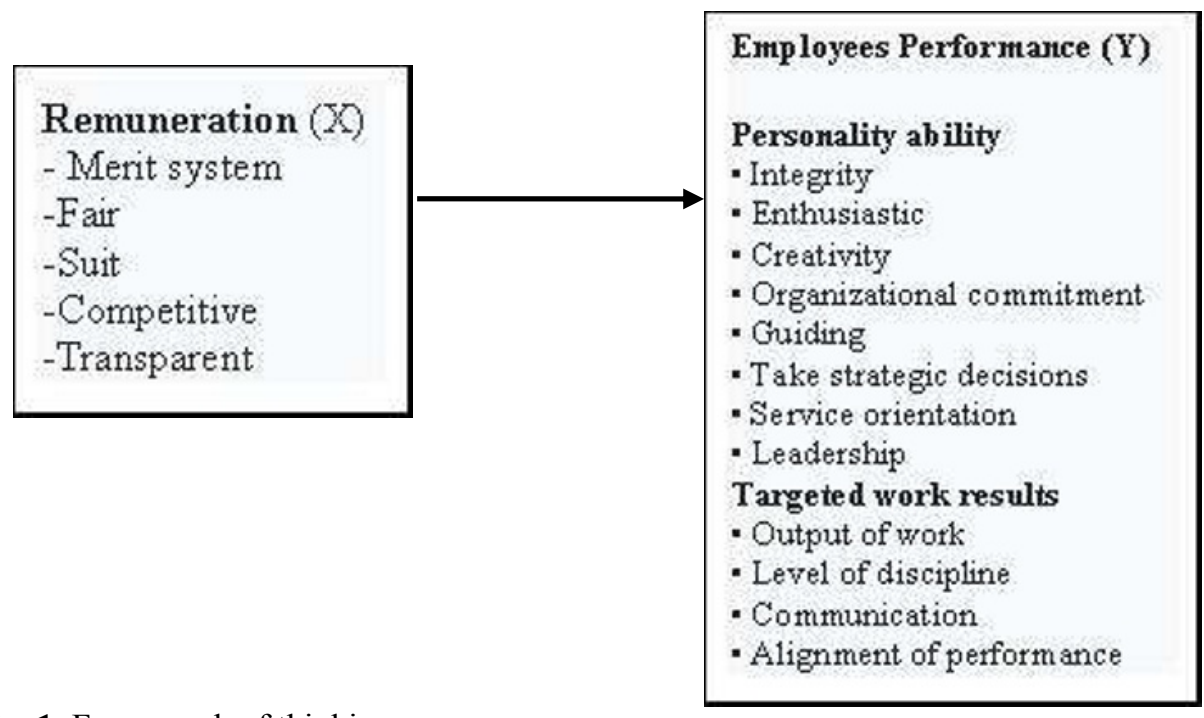

Fig. 1. Framework of thinking

Source: Retnoningtyas (2014)

\section{Figures and tables}

Object of research

The object of this study is Library Unit in Trunojoyo Madura University with 17 employees. The type of this research is qualitative research that examines participant perspectives with strategies that are interactive, flexible and more descriptive in nature. Qualitative research using qualitative descriptive research methods. Qualitative research has several strategies, Sukmadinata (2011: 61-66) said that the strategy in qualitative research is interactive and non-interactive. The interactive qualitative method is an in-depth study that uses the technique of collecting data directly from people in their natural 
environment. There are 6 (six) kinds of interactive qualitative methods, including: ethnographic studies, historical studies, phenomenology studies, case studies, basic theories, and critical studies. Non-interactive qualitative methods are analytical thinking, conducting studies based on document analysis. The data source in this study is documents. Based on the explanation above, as for this study using an interactive qualitative strategy, with the design of phenomenological study research that is, looking for meaning from experience in life, with the aim of phenomenological research is to find meaning from the basic things of life experience. The study was conducted by in-depth interviews with participants or resource persons / informants. Research informants are subjects who understand information as actors or other people who knows about the research conducted. Informants (informants) of this study amounted to 5 people who have information (data) that is a lot about the object being studied, to be asked for information about the object of the research. The informants in this study came from direct interviews which were referred to resource persons.

Using a purposive sampling techniques, namely the technique of sampling data sources based on certain considerations (Sugiyono, 2016: 218). These considerations are packaged in the characteristics of the informants that have been described in the research method. Based on the characteristics of the informant, the library staff used to be the source of this study

Research uses data collection techniques, namely: observation, interviews and documentation. The first data collection observation, the type of observation carried out by researchers was passive participation observation, explained in Sugiono (2016: 228), for this type of observation, researchers came at the activity site of the observed person but were not involved in the activity.

Researchers also use frank or disguised observation, Sugiono (2016: 228). Researchers in carrying out data collection stated frankly to the data source, that he was conducting research. The second data collection interview, the type of interview conducted by the researcher was in-depth interviews. Sugiono (2016: 223) explained that this category is a type of interview that is more free than structured interviews. Interviews were conducted with informants who had been selected by the researcher in accordance with the characteristics of the informants needed and the researchers also received approval from informants that they stated they were willing to be interviewed. Interviews were conducted with question and answer directly with interview guides set by the researcher. The third data collection is documentation, this documentation is used to produce important evidence, here the researcher took documentation when conducting interviews with informants in the form of photographs, in accordance with the agreement with the informants, in addition, photographs taken were interview notes, which were previously in the notebook then arranged by researchers in the form of transcripts of interviews presented in the results of the study in accordance with the interview guidelines used.

The steps used are editing and interpretation. This study uses data validity techniques with persistence observation techniques, checking through discussion, holding member checks, and triangulation. This study uses qualitative data analysis with the stages of reduction, presentation of data, and verification of data in order to answer the formulation of existing problems. 


\section{Equations and mathematics}

\section{Remuneration and Employee Performance}

Based on the results of observations and in-depth interviews, it is known that remuneration plays a very high role in improving employee performance. This can be seen in the behavior shown by employees when carrying out the tasks assigned to them, especially obtaining additional tasks. Employee performance moves parallel to remuneration received for the majority of employees. Likewise with the absence or lack of remuneration, it will have the same impact on employees performance. That is, if the remuneration is good, the employees performance will also increase, and vice versa.

In the field, it was found that the majority of employees benefited greatly from remuneration. Some to fulfill daily life, a small part to fulfill their lifestyle, some to cover the costs owed, some to reserve. Of all existing employees (17 people), as many as 15 employees have shown improved performance. Some indications of this increase are through timely reporting, increased creativity and innovation in anticipating institutional work programs, readiness to carry out work or additional tasks, and increasing motivation for human resource development.

This study is supported by Imam's research (2016) entitled "The Effect of Leadership, Work Motivation and Remuneration on Employee Performance at the East Java Regional Directorate General of Tax Office I". The results or findings from this study indicate that remuneration has a positive and significant effect on employees performance. Thus, good remuneration will improve performance and vice versa.

The findings of this study are also supported by the results of research conducted by Juairiah, and Rosyidah Umpu Malwa (2016) with the title of the Relationship between Giving Remuneration to Employee Performance at Siti Khadijah Islamic Hospital, Palembang, said that remuneration has increased employees performance.

In observation and in-depth interviews with employees, improving employees performance is depend on stimuli both internal (self-motivated) and external motivation such as remuneration. In this case both direct and indirect remuneration is one of the drivers of work morale and employees work productivity, by encouraging and maximizing the human resources that at last enables optimal performance to be achieved.

\section{CONCLUSIONS AND RECOMMENDATIONS}

\section{Conclusion}

1. Remuneration has a significant role in improving employees performance.

2. Remuneration is the main objective of implementing additional employees duties. Suggestion

1. It is better to pay remuneration to employees because it influences employee performance. Provision of remuneration is adjusted to the workload carried out, must be on target in accordance with the needs in the field of work, by providing socialization regarding the provision of remuneration so that there is no misperception between senior employees and new employees

2. Next study

To optimize the results of this study, it is expected that the future reviewers if with the same problem can add other variables that are deemed relevant and deeper in discussion in order to obtain maximum results. 


\section{References}

1. Bakker, A. B., \& Sanz Vergel, A. I. 2012. Weekly Work Engagement and Flourishing The Role of Hindrance and Challenge Job Demands. Journal of Vocational Behavior, Vol.83: 397-409.

2. Calvin, Ojeleye Yinka. 2017, The Impact Of Remuneration On Employees' Performance (A Study Of Abdul Gusau Polytecnic, Talata-Mafara And State College Of Education Maru, Zamfara State), Arabian Journal of Business and Management Review (Nigerian Chapter) Vol. 4, No. 2, 2017

3. Mahmudi. 2007. Public Sector Performance Management. Yogyakarta: Publishing and Printing Unit of YKPN College of Management.

4. Mangkunegara, Anwar Prabu A.A. 2009. Human Resource Management. Bandung: PT. Teenager Rosdakarya.

5. Marciano, Paul L. 2010. Carrots and Sticks Don't Work Build a Culture of Employees Engagement with the Principles of Respect. Mexico: McGraw Hill.

6. Moeheriono. 2012. Competency Based Performance Measurement. Jakarta: Raja Grafindo Persada.

7. Robbins S.P \& Judge. 2011. Organizational Behavior of the second Book. Jakarta: Salemba Empat.

8. Santoso, A., S. 2012. Development of Remuneration Model at Tugu Ibu Hospital in 2011. Hospital Administration Masters Thesis, Faculty of Public Health. University of Indonesia

9. Schaufeli, W.B., Bakker, A.B., \& Salanova, M. 2006. The Measurement of Work Engagement with a Short Questionnaire A Cross-National Study. Educational and Psychologycal Measurment, Vol. 66: 701-716.

10. Sofa. 2008. Human Resource Management. Jakarta: Bumi Aksara.

11. Pratama, Wildan Avian and Arik Prasetya. 2017. Effect of Remuneration System on Job Satisfaction and Work Motivation in Higher Education, Journal of Business Administration (JAB), Vol. 46 No.1, May 2017.

12. Juairiah, and Rosyidah Umpu Malwa. 2016. The Relationship Between Giving Remuneration to Employee Performance at Siti Khadijah Palembang Islamic Hospital, Psychic Journal, Vol. 2 No. 2 